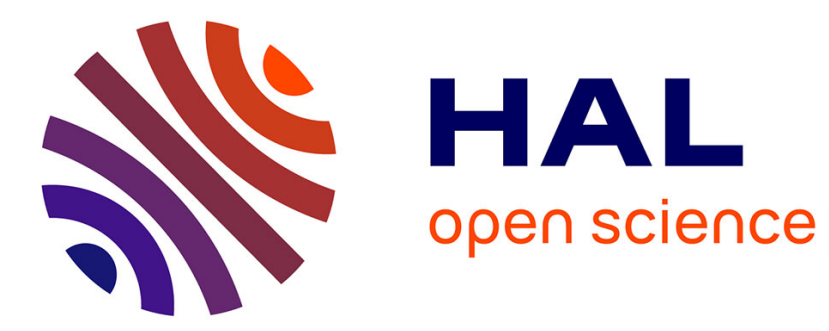

\title{
Between Regional Spaces and Spaces of Regionalism: Cross-Border Region Building in the Spanish 'State of the Autonomies'
}

\author{
Jacobo García-Álvarez, Juan Manuel Trillo-Santamaría
}

\section{To cite this version:}

Jacobo García-Álvarez, Juan Manuel Trillo-Santamaría. Between Regional Spaces and Spaces of Regionalism: Cross-Border Region Building in the Spanish 'State of the Autonomies'. Regional Studies, 2011, pp.1. 10.1080/00343404.2011.552495 . hal-00680010

\section{HAL Id: hal-00680010 https://hal.science/hal-00680010}

Submitted on 17 Mar 2012

HAL is a multi-disciplinary open access archive for the deposit and dissemination of scientific research documents, whether they are published or not. The documents may come from teaching and research institutions in France or abroad, or from public or private research centers.
L'archive ouverte pluridisciplinaire HAL, est destinée au dépôt et à la diffusion de documents scientifiques de niveau recherche, publiés ou non, émanant des établissements d'enseignement et de recherche français ou étrangers, des laboratoires publics ou privés. 


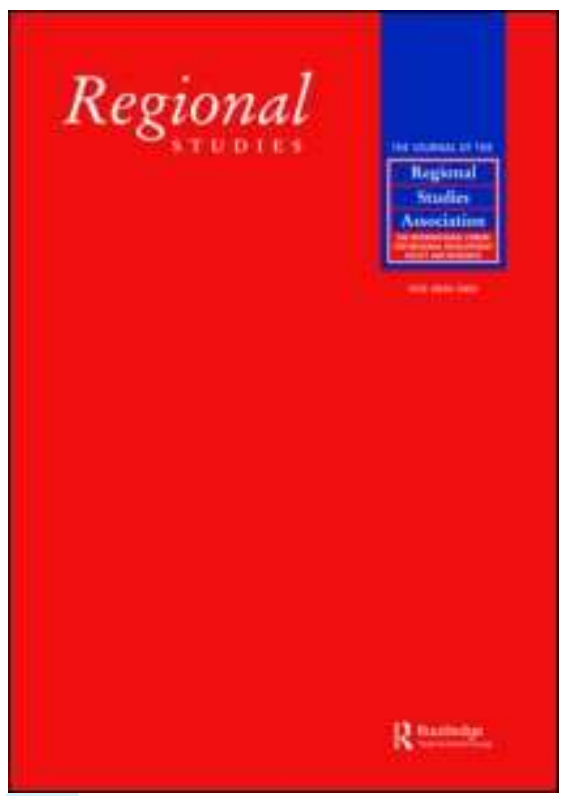

\section{Between Regional Spaces and Spaces of Regionalism: Cross- Border Region Building in the Spanish 'State of the Autonomies'}

\begin{tabular}{|r|l|}
\hline Journal: & Regional Studies \\
\hline Manuscript ID: & CRES-2010-0175.R1 \\
\hline Manuscript Type: & Special Issue Paper \\
\hline JEL codes: & $\begin{array}{l}\text { R59 - Other < R5 - Regional Government Analysis < R - Urban, } \\
\text { Rural, and Regional Economics }\end{array}$ \\
\hline Keywords: & $\begin{array}{l}\text { Border studies , Cross-border cooperation , Euroregions, Spain , } \\
\text { Basque Country, Galicia-Northern Portugal }\end{array}$ \\
\hline
\end{tabular}

\section{SCHOLARONE ${ }^{\text {m }}$ \\ Manuscripts}




\section{Between Regional Spaces and Spaces of Regionalism: Cross- Border Region Building in the Spanish 'State of the Autonomies'}

JACOBO GARCÍA-ÁLVAREZ and JUAN-MANUEL TRILLO-SANTAMARÍA Department of Humanities: History, Geography and Art, Carlos III University of Madrid, 28903 Getafe, Spain. Telephones: +34 916249209; +34 916249215; Emails: jacobo.garcia@uc3m.es and jtrillo@hum.uc3m.es

(Received May 2010: in revised form December 2010) 
Abstract: The intense development of cross-border cooperation in the European Union in the last two decades offers a privileged laboratory to reflect upon the changing nature of regions and processes of regional construction in the context of globalization.

Focusing on Euroregions, this work aims to establish some bridges between Regional World(s) and Cross-border Regional Worlds. In the first part, this kind of connections is considered under the light of the recent theoretical debates developed within the

framework of regional and border studies. The second part will focus on the analysis of cross-border cooperation in the Spanish State of the Autonomies, and particularly, on the cases of the Basque Country, Catalonia and Galicia.

Keywords: Border studies - Cross-border cooperation - Euroregions - Spain - Basque Country - Galicia-Northern Portugal

JEL Codes: R59 - Other < R5 - Regional Government Analysis < R - Urban, Rural and Regional Economics

Entre espacios regionales y espacios de regionalismo: la construcción de regiones trasfronterizas en la España de las Autonomías

Resumen: El intenso desarrollo de la cooperación transfronteriza en la Unión Europea en los últimos veinte años ofrece un laboratorio privilegiado para reflexionar sobre la naturaleza cambiante de las regiones y los procesos de construcción regional en el contexto de la globalización. Centrándonos en las eurorregiones, este artículo trata de establecer algunos puentes entre la esfera regional y la transfronteriza. En la primera parte, se examinan este tipo de conexiones sobre la base de los debates teóricos desarrollados recientemente en el marco de los estudios regionales y fronterizos. En la segunda parte, se aborda el análisis de la cooperación transfronteriza en el Estado de las Autonomías español, y de modo particular, en los casos del País Vasco, Cataluña y Galicia.

Palabras clave: Estudios fronterizos - Cooperación transfronteriza - Eurorregiones España - País Vasco - Galicia-Norte de Portugal 
1

2

3

4

5

6

7

8

9

10

\section{INTRODUCTION}

If we wish to reflect upon new "regional grammars" in a global world, it seems pertinent to turn our attention to a new type of region that has emerged in Europe as of the 1990's: the cross-border region. Furthermore, some of today's debates on the regional world can be approached from a perspective that focuses on the active processes of regional institutionalization being carried out all along the European borders.

First of all, this contribution aims to reflect in theoretical terms on some of these processes that have resulted in a great deal of literature from divergent fields, particularly in the last fifteen years. The Euroregions were conceived of institutionally as authentic micro laboratories for European integration but have also functioned as a privileged laboratory for theoretical and conceptual debate regarding borders, territorial identities and the dynamics of regional construction within the context of globalization (KAPLAN and HAKLY, 2002; GARCÍA-ÁLVAREZ, 2006a; PAASI, 2009a, 2009b; TRILLO-SANTAMARÍA, 2009). In the context of the new regional geographies and border studies, the development and recent growth of cross-border regions leads us to pose important theoretical questions in the field (PERKMANN and SUM, 2002; KRAMSCH and HOOPER, 2004; Geopolitics, special issues 10-4, 2005, 12-2, 2007 and $14-4$, forthcoming).

The first part of the article will deal with some of these questions in the light of theoretical contributions of recent years in the area of border studies, with the objective of bridging the gap between Regional World(s) and Cross-border Regional World(s).

The second part of the article will focus on the analysis of a specific case, that of cross-border cooperation in the Spanish State of the Autonomies. More precisely, this 
work shall focus on the discourses and processes that have led to the creation of Euroregions in three Autonomous Communities (hereinafter ACs,) that are located on borders and that have distinct historic and cultural personalities, the Basque Country, Catalonia and Galicia. This strong character, which is expressed in the fact that they possess their "own" language (a co-official language alongside Spanish or Castilian) politically translating into the presence of nationalist parties with varying degrees of success, has also been projected into the discourses and policies of cross-border cooperation involving these ACs (MORATA 2006; GARCÍA-ÁLVAREZ, 2006b; AJA, 2007).

As the article will state, the Euroregions created or projected in these territories are good examples of two principal elements, which in our opinion are key to understanding the genesis, success and limitations of certain cross-border cooperation processes in Europe. First, on an external level, the ACs' relations with the French and Portuguese regions bring to light the significant difference that exists between the Spanish political-territorial model, which is semi-federal, and that of its main neighboring States, which is much more centralized. Furthermore, and at the domestic level, the initiatives to establish organizations for cross-border cooperation by ACs' regional governments that include regionalist or nationalist parties often contain a politico-cultural ingredient which, in some occasions, aims at institutionalizing an ethnic Euroregion (MARKUSSE, 2004). This not only clashes with the much more functional and autocratic approach given to cross-border cooperation policies by the European Commission, but also frequently gives rise to suspicion and even opposition in the adjacent ACs' governments of other political leanings. In this regard, the article will briefly review the content of some of these initiatives in the cases of the Basque Country and Catalonia, to later focus on the institutionalization process of the 
Euroregion of Galicia/North Portugal. The analysis of these cases will incorporate some of the theoretical and conceptual instruments presented in the first section, placing special emphasis on the dialectic between (cross-border) regional spaces and (crossborder) spaces of regionalism (MACLEOD and JONES, 2007).

\section{CROSS-BORDER REGIONAL WORLD(S) WITHIN THE EUROPEAN UNION: SOME THEORETICAL REFLECTIONS}

Over the past three decades, so-called border studies have grown into a rich area of study, in which terms such as de-bordering, re-bordering, de-territorialization or reterritorialization have been established as instruments of analysis for border scholars (see, for example, NEWMAN, 2006; PAASI, 2009b). The multidisciplinary approach that prevails in this field has led some authors to propose that a new shift in social sciences should be discussed, the B/ordering turn (HOUTUM, KRAMSCH and ZIERHOFER, 2005). The ways in which regions can be considered at present should include these contributions. Our aim here is to review certain debates that directly link the Regional World to the Cross-border Regional World, in order to postulate that whatever happens to the region nowadays it seems appropriate to analyze it taking into account the particular cases of regions that straddle international borders.

Although the phenomenon of cross-border cooperation does not exclusively pertain to the European Union (hereinafter EU), it is undoubtedly in this space where its development has been the greatest, to the point that its cross-border regions have been defined as authentic micro-laboratories for European integration (VELDE and HOUTUM, 2003). In fact, the very act of naming this area of co-operation 'Euroregions' implies acceptance of this idea. Community policy has promoted their establishment, preferentially through the Interreg Community Initiative, which began in 
the 1990s. The success of this initiative has led to the creation of a specific objective within the new regional policy (2007-2013). This is known as Territorial Cooperation, which assumes, to a large extent, the main goals of the former Interreg. To this objective, the creation of a specific legal instrument has been added - the European Grouping of Territorial Cooperation (EGTC) - , instituted in 2006 by the EU to strengthen the Euroregions' capacity to act (LEVRAT, 2007). Currently, there are more than 120 Euroregions in Europe that promote putting a common agenda into practice (AEBR, 2001; PERKMANN, 2003; DEAS and LORD, 2006; Oliveras et al., 2010).

In the framework of cross-border regions, we are witness to a continuous process of overlapping, not only of local, regional and state governments and administrations, but also of different cultures, discourses and objectives of the territorial agents. Crossborder regions can be defined as new structures that, in interaction with the dimension of the agency, emerge from the encounter between two or more areas which were separated in the past by a border and which seek to cooperate, due to the border's existence (BRUNET-JAILLY, 2005). The ideas of the elite regarding cooperation, the tensions between different levels of government within a state, as well as the tensions between the diverse territorial authorities of two or more neighboring states, make this type of region a novel phenomenon in many ways.

\subsection{Cross-border regions, scales, networks, new regionalism and multi-level} governance

Adding the notion of the cross-border region to the debate about whether the world we live in is best defined in terms of scale or in terms of network can offer an interesting channel for the analysis of the processes in which scales and networks are produced and reproduced in social space (PAASI, 2004). MacLeod and Jones speculate 
as to whether the Regional World is territorial, scalar, networked or connected (MACLEOD and JONES, 2007). The answer cannot be offered in one-sided terms since the world today is at the same time scalar and networked, territorial and connected (JESSOP et. al, 2007; VARRO and LAGENDIJK, this issue). A one-dimensional explanation of the real world cannot be given; nor should a dilemma be posed between the so-called "spaces of flows" and "spaces of places" because they both coexist (CASTELLS, 1999).

Dealing with cross-border regions, Kramsch, within a more "radical" perspective, states that if we wish to think about what a cross-border region is, we must set aside our ideas about scales and re-scaling (KRAMSCH, 2007). For Kramsch "borders and border regions would not be merely the passive objects of forces operating at higher spatial scales, but would themselves become active sites for the re-theorization of fundamental aspects of political life, bearing value in turn across a range of geographical spaces" (KRAMSCH and MAMADOUH, 2003: 42). This critical vision of scalar analysis centered on regulation theory leads Kramsch to see an opportunity to define "politics transcending the borders of its member states" in the cross-border region (KRAMSCH, 2007: 1592). However, the notion of cross-border regions serving as the basis for a new democracy seems quite distant, since the majority of them are ruled by functionalist interests and have a technocratic profile (PERKMANN, 2003).

Nonetheless, specialists have widely linked the theories of new regionalism to the institutionalization processes of cross-border regions that aim to establish new political communities (PAINTER, 2008). The term cross-border regionalism was thus coined (SCOTT, 2002; PERKMANN and SUM, 2002; PROKKOLA, 2008). Crossborder cooperation is conceived of as a response to the challenges posed by globalization, and, especially, by the crisis of the nation state, which loses competences 
both from above and from below. The existence of this type of cooperation is placed, in this sense, within the global processes of multi-level governance (HOOGHE and MARKS, 2001), which has led some authors to use the term cross-border governance (KRAMSCH and HOOPER, 2004; LISSANDRELLO, 2006).

\subsection{Cross-border regions and regional institutionalization processes}

Cross-border regions offer a fertile laboratory for testing contemporary processes of regional institutionalization. Furthermore, the cross-border region represents a truly singular case within the framework of these processes, as this type of region must overcome not only the political-administrative effects typical of a state border, but also the psychological borders linked to a nation state, which in many cases seem to be equally or more difficult to overcome than the former. In this regard, it is useful to complement general analysis models of regional construction processes, such as Paasi's well-known model (1986) or Lagendijk's proposal (2007), with other theoretical contributions specifically focused on the study of cross-border regions, such as those of BRUNET-JAILLY (2005) and PERKMAN (2007). In all of them we find common elements of analysis that must be taken into account when studying the degrees of realization of the cross-border regions: cultural, symbolic, economic, political, institutional, discursive, functional, strategic, etc. The political, social and economic elite behind these processes wish to offer a new space in which to produce and reproduce social relations, projects that different specialists name "imaginary spaces" (CHURCH and REID, 1999), "cognitive regions" (SCOTT, 2000) or “anticipatory geographies" (SPARKE, 2000). The space projects linked to cross-border cooperation clearly illustrate the emergence of "unbounded regionalism" (DEAS and LORD, 2006). 
For the time being, the research carried out demonstrates the existence of a distance between the projects led by the elite and the knowledge of the population regarding the existence and functioning of cross-border regions (STRÜVER, 2005; HÄKLI, 2008). To express it in Paasi's terms, it is possible that, as far as the elite are concerned, an identity of the cross-border region has been produced (that is to say, the region has been given an identity by means of the elite's actions and discourses), but it has not yet been transformed into a cross-border regional identity (in other words, people have not yet interiorized thjs discourse) (PAASI, 1986).

\subsection{Cross-border regional spaces and cross-border spaces of regionalism}

Cross-border regions can offer regional and local agents a favorable political arena from which to project actions of paradiplomacy (ALDECOA and KEATING, 1999). This perspective is particularly clear in states that are strongly decentralized and where the sub-state regions possess ample political competences, for example, with the Spanish ACs. In this sense, it may be useful to make use of the dichotomy proposed by Jones and MacLeod between (cross-border) regional spaces and (cross-border) spaces of regionalism (JONES and MACLEOD, 2004). For these authors, a regional space "relates primarily to the work of economic geographers and scholars of regional development who - in deriving theoretical inspiration from institutional economics, evolutionary political economy and economic sociology - have uncovered successful systems of production in 'sunbelt' industrial districts and regional economies [...]". A space of regionalism, on the other hand, "features the (re-)assertion of national and regional claims to citizenship, insurgent forms of political mobilization and cultural expression and the formation of new contours of territorial government" (JONES and MACLEOD, 2004: 435). 
However, and as will be seen below when the case of Spain is analyzed, a gradient should be devised regarding the extent of the claim of the regions' political leaders in terms of politics and identity, in relation to their vision of the cross-border region. These could range from irredentist discourse, as can be seen in the Basque situation, to an eminently pragmatic and functionalist vision of external action, accompanied by a discourse of differentiated identity, as will be seen in the case of Galicia. In fact, at least in the Spanish context, it is difficult to establish a clear distinction between cross-border regional spaces and cross-border spaces of regionalism, as the political capacity of the ACs unites elements of economy, politics and identity.

In addition, to emphasize the network connections which sustain cross-border cooperation, it seems useful to integrate the dichotomies proposed by COX (1998) between space of dependence and space of engagement, and LIPIETZ (2003) between space-in-itself and space-for-itself (the latter understood in relation to the concepts of social hegemonic bloc and regional armature), as has already been done by MACLEOD (1999). Taking into account these ideas that emphasize the need for regional politicians to establish networks in various levels of government, and directing attention to the largest possible quotas of political recognition in relation to cross-border regions, this paper suggests to think either of cross-border spaces of regionalist engagement (if using Cox's terms) or of cross-border spaces of regionalism-for-itself (if drawing on Lipietz).

3. CROSS-BORDER COOPERATION IN THE SPAIN OF THE AUTONOMIES: BETWEEN REGIONAL SPACES AND SPACES OF REGIONALISM 
The activities carried out by the ACs regarding cross-border cooperation cannot be fully understood without taking into account the Spanish political-territorial model, which differs greatly from the much more centralized ones of Portugal or of France. In effect, the pillars of the territorial model of state in Spain were established in the Spanish Constitution of 1978, at the beginning of the transition to democracy after forty years of military dictatorship (GRANJA et. al. 2001; GARCÍA-ÁLVAREZ, 2002; AJA, 2007). It is an extremely decentralized model that, without being federal, is similar in many aspects to federal systems, and is based on the recognition of broad executive and legislative competences at the sub-state levels (the ACs). The originality of these regional powers created in the Spanish Constitution, but based in many cases on remote geographical and historical precedents, frequently leads experts to call the Spanish territorial model the Autonomous State or the State of the Autonomies. The strong geographical and cultural diversity within the country, together with other historical and political factors, have translated into the existence of numerous sub-state parties of a regionalist or nationalist nature. This section will focus on the case of Catalonia, the Basque Country and Galicia, outlying ACs on the border which have co-official languages other than Spanish. In these regions the weight of the nationalist parties has certainly been relevant, although also uneven.

In the case of the Basque Country, the nationalist and conservative Basque Nationalist Party (PNV), stayed in power from 1980 governing alone or in coalition until recently. In the March 2009 regional elections, the Socialist Party of Euskadi (PSE-PSOE), a regional branch of the Socialist Workers' Party of Spain (PSOE), took power through a pact with the Basque Country People's Party (PP). Regarding Catalonia, Convergence and Union ( $\mathrm{CiU})$, also a nationalist and conservative party, 
governed the Autonomous Community from 1980 to 2003, when the Socialist Party of Catalonia (PSC), a federalist formation associated with (although independent from) the Socialist Workers' Party of Spain (PSOE), entered the regional government in coalition with the Republican Left of Catalonia (ERC), a left-wing pro-independence party. Finally, the People's Party of Galicia (PPdeG), representative of a conservative ideology with regionalism leanings, has governed the Autonomous Community from 1990 to the present day except for the period 2005-2009, when a coalition of the Galician Socialist Party (PSdeG) and the Galician Nationalist Bloc (BNG) governed.

\subsection{Cross-border spaces of regionalist engagement in conflict with other}

\section{ACs: Basque Country and Catalonia}

The first example of cross-border cooperation body on the Iberian Peninsula is in 1983, the year in which the Work Community of the Pyrenees was established by the ACs of Aragon, Catalonia, Navarre and Basque Country, the French regions of Aquitaine, Languedoc-Rousillon and Midi-Pyrenees, and the Principality of Andorra. It is the only agreement prior to the launching of the Interreg Community Initiative, which was quickly revealed to be a true "window of change" (LAGENDIJK, 2007) for the starting up of various cooperation bodies. Regionally speaking, all ACs currently participate in some institutional framework in common with Portuguese or French regions, respectively (MPT, 2010). These cooperation bodies are legally grounded in agreements signed by the Spanish government with both the French government (Treaty of Bayonne, 1995) and the Portuguese government (Treaty of Valencia, 2003), which regulate the specific conditions for the application of the 1981 European Outline on Transfrontier Cooperation between Territorial Communities or Authorities (MARTÍNEZ, 2006). 
The importance given to cross-border cooperation by the Spanish ACs has been increasing since the 1990s. The first decade of 2000 has been very significant in this regard, as proven by the reforms approved over the last few years in the Statutes of Autonomy of several Spanish ACs. Regarding external action, and specifically crossborder cooperation, all the new Statutes approved to date explicitly include the regional governments' right to carry out policies of cross-border cooperation (GARCÍA, 2009). In addition, the ACs' growing interest in cross-border cooperation can be seen clearly in their respective spatial planning plans, as well as in the actions of those in charge of community and foreign policy for the respective autonomous governments. But although external action and cross-border cooperation in most ACs are fundamentally viewed in terms of strengthening economic and territorial development, in others, such as those governed by nationalist parties, these actions are mixed with other types of political and territorial discourses and projects, such as those geared towards national construction itself (DOMÍNGUEZ, 2005; GARCÍA-ÁLVAREZ, 2006b; MORATA, 2006).

The case of the Autonomous Community of the Basque Country (or Euskadi) is perhaps the most significant in this regard, although it is not the only one. In October 2003, the government of this community, then presided over by the PNV, publicly presented a new Statute of the Community of Euskadi known popularly by the name of its key proponent, Juan José Ibarretxe, president of the regional government between 1999 and 2009. The "Ibarretxe Plan", which was approved in the Basque Parliament with the support of the autonomous nationalist parties, was later rejected by the Spanish Parliament in February 2005 by a large majority. Without entering into the reasons why the Spanish Parliament voted against the plan, the Ibarretxe plan illustrates in exemplary fashion the projection of a cross-border space of regionalist engagement. Moreover, the 
plan conceives of cross-border cooperation as an instrument for legitimizing the territorial objectives pursued by the Basque nationalist parties, which focus on the political unification of the territorial area they call Euskal Herria or Greater Basque Country (BECK, 2006) (Fig. 1). According to Basque Nationalism, the territory of Euskal Herria (which literally means "land of the Basque language") would include the Autonomous Community of the Basque Country and the Foral Community of Navarre in Spain and the eastern part of the French Département of Atlantic Pyrenees (the historic provinces of Labourd, Lower Navarre and Soule), which belong to the Aquitaine Region.

Fig. 1. Territorial components of Euskal Herria, according to Basque nationalist imagination

The preamble of the latest version of the Ibarretxe Plan explicitly states that the Basque people or Euskal Herria is divided into seven territories, and that the Autonomous Community of Euskadi is simply an integral part of it. Likewise, article 2 of the Plan aims at the possibility of establishing "some common territorial framework for relations" among the Basque territories and article 66.2, which forms part of Title VI (dedicated to the political relations of Euskadi with the European and international sectors), indicates what it considers the most adequate institutional framework for it within the European context: the establishment of a Euroregion.

"The Community of Euskadi will promote the creation of a Euroregion within the European Union that includes the historic territories that make up Euskal Herria and, if appropriate, other nearby regions with which it maintains historic, economic and cultural links of singular importance." (PREPCE, 2005). 
After the Plan was rejected in the Spanish Parliament, the PNV did not give up the idea of creating a Basque Euroregion as a useful administrative framework to advance in the nation building of Euskal Herria, an idea extensively defended by certain academic experts in favor of nationalism (LETAMENDÍA, 1997; AHEDO et al., 2004). Thus, for example, at what are known as the Loyola Negotiations (September and October 2006), in which the Spanish government together with representatives from the Basque political parties (PSE-PSOE, PNV) and Batasuna (a political organization that was illegalized due to its ties to the terrorist group ETA) held conversations with ETA to attempt to achieve an end to terrorist activity, the PNV proposed the possible formation of a Basque Euroregion as a solution to the conflict (OYARZÁBAL, 2008).

As Markusse indicated, the establishment of an "ethnic" Euroregion on the basis of Euskal Herria does not seem viable today, among other reasons, because the territories of French Basque Country do not have any sort of territorial power, and cooperation agreements of this type must be established regionally, that is, between Euskadi and Aquitaine (MARKUSSE, 2004). In addition to this, the aims of the former Basque government to establish some sort of framework of joint cooperation in what is called Euskal Herria clash head-on with the opinion of the government of the Autonomous Community of Navarre, led by the Union of the People of Navarre (UPN) and presided over by Miguel Sanz, who have traditionally defended Navarre's singularity against the Basque Country. Due precisely to the irredentist discourse that emanates from the possibility of actually establishing Euskal Herria, the Navarre government has shown itself to be reluctant to participate in cross-border cooperation initiatives led by the Basque Country. Actually, whereas between 1991 and 2000 Navarre participated in a collaboration pact with Euskadi and Aquitaine, it stopped 
doing so in 2000 because, following an ETA terrorist attack, the PNV government did not break its ties with its partner at that time, Euskal Herritarrok, a political party linked to ETA and in favor, as is ETA, of the creation of an independent state in the area of Euskal Herria.

President Sanz's reticence to collaborate in any cross-border cooperation organization that includes the Basque Autonomous Community has continued, even with the recent change of government of this Community, now led by the PSE-PSOE which has substituted PNV's nationalist discourse for one that is regionalist or at least constitutionalist, and which does not enter into conflict with the state. Thus, on the 30th of November 2009, while regional presidents Alain Rousset (Aquitaine) and Francisco Javier López (Basque Country) signed an agreement to establish a new AquitaineEuskadi Euroregion through the EGCT legal classification, in which the Navarre government was also invited to participate, Sanz was quick to decline the invitation the very next day.

Similarly, the reactions of certain Spanish regional politicians when faced with the proposal of the former president of the Catalan government, Pasqual Maragall, of the PSC, to establish the Pyrenees-Mediterranean Euroregion can be cited. In the summer of 2003 Maragall presented his project, which would include the ACs of Aragon, Catalonia, the Balearic Islands and the Valencian Community and the French regions of Languedoc-Roussillon and Midi-Pyrénées. To legitimize his proposal, and in addition to other eminently geo-economic arguments, Maragall referred to both the historical concept of the Crown of Aragon and that of the Catalan Countries (Països Catalans), which would be made up of all the territories where Catalan is spoken, both inside and outside Spain (BOIRA, 2002; DÍEZ and PINAZO, 2005; PRYTHERCH, 2009). 
The fiercest reactions to the proposal of creating a Euroregion came from the regional government of the Valencian Community, in the hands of the People's Party. Its president, Francisco Camps, went so far as to brand the initiative as unconstitutional, because "it attempts to usurp the dialogue and the capacity for decision of the ACs", as well as representing a "real danger for the institutional and territorial stability of Spain". The Euroregion proposal, added Camps, "would take on competences of our Community, taking away autonomy from the Community, and rob us of part of our own autonomy” (ABC, 30-VIII-2003; SUÁREZ and RODRÍGUEZ, 2008).

These words demonstrate the strong reactions that the politics of cross-border cooperation provoke when they are mixed with certain nationalist projects or, more broadly, with arguments regarding identity, which may make us forget that on the Iberian Peninsula there already existed numerous cases of cooperation institutions that in no case went against the Constitution nor endangered the territorial model in effect. The Pyrenees-Mediterranean Euroregion got off the ground in 2004 without the presence of the Valencian Community. In May, 2006, the government of the AC of Aragon also decided to abandon the Euroregion, in this case due to a conflict with the Catalan government over the ownership of certain pieces of sacred art.

\subsection{The Galicia-Northern Portugal Euroregion: conceptions at stake and} processes of institutionalization

Political contacts between the government of the Autonomous Community of Galicia (Xunta de Galicia) and the representatives of the Portugal North Region began in the 1980s, although it was in the 1990s when they intensified. The determined commitment of two principal political leaders at that time, Manuel Fraga on behalf of Galicia and Luis Braga da Cruz on behalf of Portugal, led to the constitution of the 
Galicia-Northern Portugal Working Community in 1991, the first cross-border cooperation institution on the Spain-Portugal border (CORDAL, 2009). Since then, the Galician governments have decisively committed to external action focused on Portugal, and especially on the Portugal North Region. This can be explained both by cultural, linguistic and custom similarities with the North region and by economic interests (LOIS, 2004; LABRAÑA et al., 2004; PALMEIRO, 2009). On the one hand, from a historical and cultural point of view, the fact that Galician and Portuguese languages have the same root, Gallego-Portuguese, from Latin, should not be overlooked. Present-day Galicia and the North Portugal Region made up part of a province called Gallaecia in the age of the Roman Empire (Nogueira, 2002). In the times of the Reconquista, the territories that gave rise to the Kingdom of Portugal also belonged to the Kingdom of Galicia (and, within this area, that of León) until 1139, when the Count of Portugal, Alfonso Henriques, officially became an independent king.

On the other hand, the economic interests of establishing a Euroregion should not be underestimated. The Working Community manages all the European funds corresponding to the Operational Program of Cross-border cooperation Spain-Portugal. The last joint document made by regional politicians to establish the master lines of action dates from 2007 (Strategic Plan of Cross-border cooperation Galicia/North Portugal), and refers to the 2007-2013 European regional policy programming period, within the framework of the Territorial Cooperation Objective. In the first call for projects (2007-2009), the aforementioned Operational Program received nearly 42 million Euros, of which 31.5 million were from the European Regional Development Fund. The Eurorregion covers an area of $50,862 \mathrm{Km}^{2}$ and has a population of $6,529,608$ inhabitants (as of January 1, 2008). 
1

2

3

4

5

6

7

8

9

10

As has been pointed out, the Galician government was presided over for the greater part of the last twenty years by the PPdeG which held power in the region continuously from 1990 to June 2005, when the PSdeG-BNG coalition came to power. In April 2009, the regional elections were won by the present Xunta president, Alberto Nuñez Feijoo (PPG). Over the past years on various occasions, these three parties have expressed their visions of cross-border cooperation, in which there are more similarities than differences. In order to illustrate the main similarities, it is only necessary to recall two documents that were written close in time regarding the strategic lines of external action of the last two Galician governments, one from 2004 (Libro Blanco de la Acción Exterior), and another from 2007 (Estrategias de la Acción Exterior). Both indicate the necessity of guiding Galician external action toward the Lusophone world, and very particularly toward Portugal. In addition, they confirm the importance that the Euroregion has for Galicia to be able to project itself outwards in an area where it must be an engine of economic, political and cultural development.

But, at the same time, cross-border cooperation has been fully integrated into the political debate, and is even a cause for partisan disputes. The electoral programs of the three parties (PPdeG, PSdeG and BNG) for the March 2009 regional elections illustrate some of the differences in the way these matters are viewed. The one that places least emphasis on cross-border cooperation is the BNG, because its discourse revolves around a more general project of relations with the Lusophone world, in which "cultural reintegration in the Galician-Portuguese world as a normalizing factor" is especially developed. For the PSdeG, the intensification of relations with North Portugal through the impetus of the EGCT is accentuated. Finally, the PPdeG dedicates a specific section to cross-border cooperation, in which it criticizes the previous government's policy, and proposes a model of greater integration and development. 
In summary, cross-border cooperation with the North Region is viewed as a line of action of Galician external policy, and it does not provoke great differences of opinion among the three parties. In no case is there (at least from an official point of view) the irredentist approach, as it has been shown, in the institutional discourse of Basque nationalism.

However, in order to properly understand the meaning of cross-border cooperation both for Galicia and the North Region, we must not forget that we are in the presence of a phenomenon of the overlapping of two very different political-territorial models. Compared to the deeply decentralized model of the Spanish State, the Portuguese model is characterized by its centralism. Thus, while the ACs possess their own power at the legislative, executive and judicial levels, the Portuguese Regions, with the exception of Madeira and the Azores, lack any sort of political autonomy. Apart from the two exceptions mentioned, which have the category of Autonomous Regions, the regional territorial and administrative structure in Portugal comes from the Regional Commissions of Coordination and Development (in total five, of which the North region is one), deconcentrated entities that are dependant on the central government, created by Decree-Law of May 23, 2003 on the basis of the earlier regions of planning. This essential difference between Spanish ACs and what are known as the Portuguese Regions means that cross-border cooperation between them is a tremendously complex phenomenon in political and administrative terms. In fact, on occasion, representatives of the Galician government, by virtue of their competences, must sit down to negotiate directly with representatives of the Portuguese government.

Furthermore, this overlapped territorial system translates into important differences in the way cross-border cooperation is conceived. Thus, while in Galicia cross-border cooperation with Northern Portugal is considered to be a fundamental part 
of the Autonomous Community's external action, in Portugal this cooperation is best understood linked to the development of the northern area of the country. In other words, what is called the Galicia-Northern Portugal Euroregion is projected as a crossborder space of regionalist engagement (or a cross-border space of regionalism-foritself), but for the Portuguese agents it means instead a cross-border regional space of engagement.

The principal documents of spatial planning recently prepared on either side of the border clearly illustrate these differences. On one hand, the Directives of Territorial Management of Galicia, the draft of which was initially approved by the autonomous government in 2008 (Diario Oficial de Galicia, 17-IX-2008), deals with the GaliciaNorthern Portugal Euroregion as a space around which all the external connections of the Autonomous Community revolve. The very presence of the term "Euroregion" in the document is significant, as it appears 20 times, while the word Portugal is mentioned 33 times and the word Spain 10 times. The Portuguese vision, however, as is expressed in the Regional Plan of Territorial Management of the North Region, the draft of which was presented in December 2009 (www.ccr-norte.pt), deals with the external connectivity of the North Region, not only with Galicia, but also with the Autonomous Community of Castile and León, with which it also borders and participates in a Working Community. The term Galicia-Northern Portugal Euroregion is only cited seven times, although its ultimate meaning is linked to specific projects more than to a global strategy for external action.

Nonetheless, certain Portuguese politicians (especially those belonging to the Socialist Party) may see in the broad competences of their Galician neighbor a path to claims in favor of the political or administrative regionalization of the Portuguese State, a matter which has led to important debates and initiatives over the last fifteen years 
(FERNANDES, 2008). Therefore, the Euroregion could even be considered from the Portuguese side as a cross-border space of regionalist engagement.

In short, what this contribution tries to show is that in order to analyze the role that a cross-border cooperation body can play in internal and external politics of the states and regions, the integral parts must be considered separately. Of course, this kind of cross-border institutions must be considered as a whole as well. In this regard, the Galicia-Northern Portugal Euroregion is conceived of as a cross-border space of engagement in the European context connected to different networks. Thus, both the Autonomous Community of Galicia and the North of Portugal Regional Commission of Coordination and Development belong to the Conference of Peripheral Maritime Regional and the Atlantic Arc Commission, while the "Eixo Atlántico do Noroeste Peninsular" municipal Association (one of the members of the Working Community) participates in several networks at the state and European level.

To conclude this section, it is interesting to consider, if briefly, the institutionalization processes of the cross-border region. Among the joint institutional bodies, first of all, the aforementioned Working Community should be mentioned. In addition to forming part of the Xunta de Galicia and the North Regional Commission of Coordination and Development, it is made up of five local organizations: four Territorial Communities and the aforementioned association of cities called "Eixo Atlántico" (Fig.2). We must add to this the recent creation of an EGCT called Galicia/North Portugal EGCT (GNP-ECGT), which does not replace the Working Community, and is only made up of regional powers. The universities of Galicia and of North Portugal have also initiated a cooperation project within the foundation called FCEER (Galicia-North Portugal Center of Euroregional Studies Foundation), which 
began to function in 2004. This foundation aims to create itself as a forum in which teachers and students can exchange experiences and knowledge about the Euroregion.

Fig. 2. Cross-border cooperation spatial structures in the Galicia-North of Portugal Euroregion

Regarding the production of discourse legitimizing the existence of the Euroregion, the activity carried out by the Eixo Atlántico association, made up of 34 Galician and Portuguese cities, stands out. Its work is not limited to the analysis of member cities, but rather extends to the Euroregion area (www.eixoatlantico.com). Its work reinforces the production of an "institutional thickness" (AMIN and THRIFT, 1994) or "cross-border regional armature" (LIPIETZ, 2003); also corresponding to the territorial and symbolic shapes of Paasi's model (PAASI, 1986), or to the building of an identity for the Euroregion that is not only functional or strategic, but also cultural (HOUTUM and LAGENDIJK, 2001).

The Association promotes studies in diverse areas such as social development, transport, sustainable development, culture and tourism, publishing extensively. Furthermore, we must emphasize the publication of two detailed studies on the political, economic, cultural and social situation of the Euroregion, published in 1995 and 2005 respectively, called Estudios Estratéxicos. Added to that is the publication, since May 2001, of the Revista da Eurorrexión Galicia-Norte de Portugal, with 16 issues published by the end of 2009 .

The Euroregion institutions have also driven certain actions aimed at building regional imagery, identity and awareness that can be shared by Euroregion inhabitants. In this regard, academic papers such as A Historia no Eixo Atlántico (1999), Xeografía do Eixo Atlántico (1999) and Atlas do Eixo Atlántico e Eurorrexión Galiza e Norte de 
Portugal (2007) or the 12-part series titled Eurorrexión século XXI. Galicia-Norte de Portugal (2006) stand out. In all these, the underlying intention is to establish - in Scott's terms - a new “cross-border cognitive region” (SCOTT, 2000), even making use of the Gallaecia reference point to appeal to a foundational and common historic space between the Spanish and Portuguese States that had been artificially divided. The organization of numerous cultural and sporting events in which the inhabitants from both sides of the border participate, also attempts to foster the idea of a shared territory (TRILLO-SANTAMARÍA, 2010). However, the success of such initiatives seems to be, at present, relatively limited, and it is not possible to talk about a cross-border regional identity at the heart of the Euroregion (SOUTO, 2005; RODRÍGUEZ et al., 2006). Despite political discourse that openly promotes "second generation" cross-border cooperation to truly reach the citizens, these projects are still far removed from daily life.

\section{CONCLUSIONS}

Cross-border regions seem to offer suitable contexts for putting into practice the analytical instruments for regional studies, to bridge the gap between Regional World $(s)$ and Cross-border Regional World(s).

The political context within which the various initiatives of cross-border cooperation are framed should be taken into account in order to understand their complexity. The examination of three regional cases that are representative of the Spanish State of the Autonomies (three border regions which have a strong cultural and linguistic identity) enables us to see some key problems associated with the building of 
cross-border spaces within the EU, as well as the usefulness, but also the limitations, of certain recently posed conceptualizations of the region.

In Spain, Cross-Border Cooperation cannot be separated from the debates about the political and territorial model of the state and the dialectic between national and regional identities. As this article has tried to show, in some ACs with strong sub-state nationalist parties, cross-border cooperation policies can also be used as ideological instruments to put into question the state's territory and national sovereignty and, furthermore, the "Europe of the States". In any case, the three examples that have been commented on present similarities, but also considerable differences when it comes to understanding the complex dialectic between the regional spaces and spaces of regionalism that characterize the origin of the State of the Autonomies.

The Basque case, where recent plans to create a Basque Euroregion have been closely linked to territorial projects of nationalism, can be analyzed as a clear example of cross-border space of regionalist engagement of irredentist shades. Compared to the more economic and technocratic perspective of the Europe of Regions, the proposals of Basque Nationalism openly place themselves, as this type of project proves, in defense of the Europe of Peoples, which has an ethno-territorial outlook. The construction of the Euroregion is in fact viewed as a path towards the construction of a Basque nation. Regarding the other two cases that have been analyzed, while we cannot speak of irredentism, the demand for a cultural space that transcends both internal borders between ACs and external ones between states can be observed. That is what occurs, above all, with the idea of "Països Catalans", closely present in certain Euroregional imagery connected with Catalan Nationalism, and, although to a lesser degree, with the geographical and historical references used in relation to the Galicia/North Portugal Euroregion. 
The connection between internal and external Spanish politics, focused on cross-border cooperation, has been made manifest in the adverse reaction of the Foral Region of Navarre regarding the projects led by the governments of the Basque Country, and that of the Valencian Community in the case of the PyreneesMediterranean Euroregion project led by the former Catalan president Maragall.

Finally, the analysis of the Galicia-North Portugal Euroregion, the subject of the last section of the article, has served, first of all, to illustrate the difficulties of building cross-border cooperation institutions between two states that possess different models of territorial organization. Being endowed with many more political competences than their Portuguese counterparts, Galician regional politicians view the Euroregion as an instrument of paradiplomacy, whereas North Portuguese authorities mainly think of cross-border cooperation in functional terms. Secondly, the study of the Galicia-North Portugal case has shown some of the main aspects of the institutionalization processes of cross-border regions in the Iberian Peninsula, whose discourses and initiatives are still far removed from the daily lives of its inhabitants.

Acknowledgement - The authors wish to thank A. Paasi for his comments on earlier versions of this paper, and also the comments provided by the anonymous referees. The usual disclaimers apply.

\section{REFERENCES}

AEBR (2001) Transeuropean cooperation between territorial authorities. ARFE, Gronau. 
1

2

3

4

5

6

7

8

9

10

11

12

13

14

15

16

17

18

19

20

21

22

23

24

25

26

27

28

29

30

31

32

33

34

35

36

37

38

39

40

41

42

43

44

45

46

47

48

49

50

51

52

53

54

55

56

57

58

59

60

AHEDO I. et al. (2004) Redes transfronterizas intervascas. Universidad del País Vasco, Bilbao.

AJA, E. (2007) El Estado autonómico. Federalismo y hechos diferenciales. Alianza, Madrid.

ALDECOA F. and KEATING M. (Eds) (1999) Paradiplomacy in action: the foreign relations of subnational governments. Frank Cass, London.

AMIN A. and THRIFT N. (1994) Living in the global, in AMIN A. and THRIFT N. (Eds) Globalization, Institutions, and Regional Development in Europe, pp. 1-22. Oxford University Press, Oxford.

BECK J. M. (2006) Geopolitical imaginations of the Basque Homeland, Geopolitics 11, $507-528$.

GRANJA, J. L. et al. (2001) La España de los nacionalismos y las Autonomías. Síntesis, Madrid.

BOIRA J.V. (2002) Euram 2010. La via europea. Eliseu Climent, Valencia.

BRUNET-JAILLY E. (2005) Theorizing borders: an interdisciplinary perspective, Geopolitics 10(4), 633-649.

CASTELLS M. (1999) Grassrooting the space of flows, Urban Geography 4, 294-302. 
CORDAL C. (2009) A acción exterior galega e as relacións con Portugal, Tempo Exterior 18, 153-162.

COX K. (1998) Spaces of dependence, spaces of engagement and the politics of scale, or: looking for local politics, Political Geography 17(1), 1-23.

DEAS I. and LORD A. (2006) From a New Regionalism to an Unusual Regionalism?, Urban Studies 43(10), 1847-1877.

DÍEZ J. and PINAZO J. (2005) La Eurorregión Pirineos-Mediterráneo: una evaluación estratégica, Cuadernos Constitucionales de la Cátedra Fadrique Furió Cerol 52/53, $119-140$.

DOMÍNGUEZ F. (2005) Las regiones con competencias legislativas: un estudio comparado de su posición constitucional en sus respectivos Estados y en la Unión Europea. Tirant lo Blanch, Valencia.

FERNANDES J.L. (2008) El model de desenvolupament i l'organització territorial a Portugal. Inèrcies, desafiaments y oportunitats, in TORT, J. et. al. (Eds) L'organització del territori, pp. 353-402. Universitat Catalana d'Estiu-Galerada, Barcelona.

GARCÍA R. (dir.) (2009) La acción exterior de las Comunidades Autónomas en las reformas estatutarias. Tecnos, Madrid.

GARCÍA-ÁLVAREZ J. (2002) Provincias, regiones y comunidades autónomas: la formación del mapa político de España. Secretaría General del Senado, Madrid. 
GARCÍA-ÁLVAREZ J. (2003) Territorio y nacionalismo: la construcción geográfica de la identidad gallega (1860-1936). Xunta de Galicia, Santiago de Compostela.

GARCÍA-ÁLVAREZ J. (2006a) Geografía regional, in HIERNAUX, D. and LINDON, A. (Dirs) Tratado de Geografía Humana, pp. 25-70. Anthropos-Universidad Autónoma Metropolitana, Barcelona.

GARCÍA-ÁLVAREZ J. (2006b) Territoire, questions régionales et dimension européenne dans l'Espagne des Autonomies: réalisations et défis, Rives nordméditerranéennes 25, 31-42.

HÄKLI J. (2008) Re-Bordering Spaces, in COX, K., LOW, M. and ROBINSON, J. (Eds) The SAGE Handbook of Political Geography, pp. 471-482. Sage, London.

HOOGHE L. and MARKS G. (2001) Multi-level governance and European integration. Rowman \& Littlefield, Lanham.

HOUTUM H. van and LAGENDIJK A. (2001) Contextualising regional identity and imagination in the construction of polycentric urban regions: the cases of the Ruhr Area and the Basque country, Urban Studies 38(4), 747-767.

HOUTUM H. van, KRAMSCH O. and ZIERHOFER W. (Eds) (2005) B/Ordering Space. Ashgate, Aldershot. 
JESSOP B., BRENNER N. and JONES M. (2007) Theorizing Socio-Spatial Relations, Environment and Planning D: Society and Space 26(3), 389-401.

JONES M. and MACLEOD G. (2004) Regional spaces, spaces of regionalism: territory, insurgent politics and the English question, Transactions of the Institute of British Geographers 29, 433-452.

KAPLAN D.H. and HAKLI J. (Eds) (2002) Boundaries and Place: European Borderlands in Geographical Context. Rowman and Littlefield, Lanham.

KONRAD V. and NICOL H. (2008) Beyond Walls: Re-inventing the Canada-United States Borderlands. Ashgate, Aldershot.

KRAMSCH O. (2007) Querying cosmopolis at the border of Europe, Environment and Planning A 39, 1582-1600.

KRAMSCH O. and HOOPER B. (2004) (Eds) Cross-border governance in the European Union. Routledge, Oxford, New York.

LABRAÑA S. et al. (2004) A raia galego-portuguesa em debate, in MARQUEZ J.A. and GORDO M. (Eds) Fronteras en movimiento, pp. 153-176. MEC, Huelva.

LAGENDIJK A. (2007) The Accident of the Region: A Strategic Relational Perspective on the Construction of the Region’s Significance, Regional Studies 41, 1193-1207. 
1

2

3

4

5

6

7

8

9

10

11

12

13

14

15

16

17

LETAMENDÍA F. (1997) Basque nationalism and cross border cooperation between the Southern and the Northern Basque Countries, Regional \& Federal Studies 7(2), 2541.

LEVRAT N. (2007) The European Grouping of Territorial Cooperation. CdR (117/2007, Study).

LIPIETZ A. (2003) The National and the Regional: Their Autonomy Vis-à-Vis the Capitalist World Crisis, in BRENNER N., JESSOP B., JONES M. and MACLEOD G. (Eds) State-Space: A Reader, pp. 239-255. Oxford, Blackwell.

LISSANDRELLO E. (2006) The Utopia of Cross-Border Regions. Territorial Transformation and Cross-Border Governance on Espace Mont-Blanc. Phd Thesis Radboud University Nijmegen.

LOIS R. (2004) Galice-Portugal: des rélations transnationales privilegiées dans la Peninsule Iberique, Sud-Ouest Européen: révue géographique des Pyrénées et du SudOuest 18, 31-40.

MACLEOD G. (1999) Place, Politics and 'Scale Dependence': Exploring the Structuration of Euro-regionalism, European Urban and Regional Studies 6(3), 231253. 
MACLEOD G. and JONES, M. (2007) Territorial, scalar, networked, connected: in what sense a 'Regional World'?, Regional Studies 41(9), 1177-1191.

MARKUSSE J. (2004) Transborder Regional Alliances in Europe: Chances for Ethnic Euroregions?, Geopolitics 9(3), 649-673.

MARTÍNEZ E. (Coord.) (2006) La adaptación de los organismos de cooperación transfronteriza por las Comunidades Autónomas. GIT, Valladolid.

MINISTERIO DE POLÍTICA TERRITORIAL (MPT) (2010) La cooperación transfronteriza realizada por las entidades territoriales españolas. MPT, Madrid.

MORATA F. (2006) European Integration and the Spanish 'State of the Autonomies', ZSE 4, 507-528.

NEWMAN, D. (2006) Borders and Bordering: Towards an Interdisciplinary Dialogue, European Journal of Social Theory 9(2), pp. 171-186.

NOGUEIRA C. (2002) A memoria da nación: o reino de Gallaecia. Xerais, Vigo.

OLIVERAS, X., DURÀ, A. and PERKMANN, M. (2010) Las regiones transfronterizas: balance de la regionalización de la cooperación transfronteriza en Europa (1958-2007), Documents d'Anàlisi Geogràfica 56(1), 21-40. 
1

2

3

4

5

6

7

8

9

10

11

12

13

14

15

16

17

18

19

20

21

OYARZÁBAL J. (2008) Las verdaderas intenciones del PNV: negociación, Loyola y referéndum, GEES, nº 2278.

PAASI A. (1986) The institutionalization of regions: a theoretical framework for understanding the emergence of regions and the constitution of regional identity, Fennia 164(1), 105-146.

PAASI A. (2004) Place and region: looking through the prism of scale, Progress in Human Geography 28(4), 536-46.

PAASI A. (2009a) The resurgence of the Region and Regional Identity: theoretical perspectives and empirical observations on regional dynamics in Europe, Review of International Studies 35, 121-146.

PAASI A. (2009b) Bounded spaces in a 'borderless world': border studies, power and the anatomy of territory, Journal of Power 2(2), 213-234.

PAINTER J. (2008) Cartographic anxiety and the search for regionality, Environment and planning A 40 (2), 342-361.

PALMEIRO J. L. (2009) Transborder Cooperation and Identities in Galicia and Northern Portugal, Geopolitics 14, 79-107.

PERKMANN M. (2003) Cross-border regions in Europe - Significance and drivers of regional cross-border co-operation, European Urban and Regional Studies 10, 153-171. 
PERKMANN M. (2007) Construction of new territorial scales: a framework and case study if the EUREGIO cross-border region, Regional Studies 41(2), 252-253.

PERKMANN M. and SUM N.L. (Eds) (2002) Globalization, Regionalization and Cross-border regions. Palgrave Macmillan, Basingstoke.

PROKKOLA E.V. (2008) Making bridges, removing barriers. Cross-border cooperation, regionalization and identity at the Finish-Swedish border, Nordia Geographical Publications 37(3).

PREPCE (2005) Propuesta de Reforma de Estatuto Político de la Comunidad de Euskadi, Boletín Oficial de las Cortes Generales, 21-I-2005.

PRYTHERCH D. L. (2009) New Eurorregional Territories, Old Catalanists Dreams?: Articulating Culture, Economy and Territory in the Mediterranean Arc, European Urban and Regional Studies 16 (2), 131-145.

RODRÍGUEZ R. et al. (2006) El Eixo Atlántico del Noroeste Peninsular, in FARINÓS J. and ROMERO, J. Gobernanza territorial en España, pp. 123-136. Valencia, Universitat de València.

SCOTT J. (2000) Euroregions, governance, and transborder cooperation within the EU, in Van der VELDE, M. and HOUTUM, H. van (Eds) Borders, Regions and People, pp. 104-115. Pion, London.

SCOTT J. (2002) A Networked Space of Meaning? Spatial Politics as Geostrategies of European Integration, Space \& Polity 6(2), 147-167. 
SUÁREZ C. and RODRÍGUEZ P. (2008) L'Euroregió Pirineus-Mediterrània, Working

STRÜVER A. (2005) Stories of the 'Boring Border': The Dutch-German Borderscape in People's Minds _LIT-Verlag, Münster.

Papers on Line (WPOL), $n^{\circ} 18$, Institut Universitari d'Estudis Europeos.

TRILLO-SANTAMARÍA J. M. (2009) "De la frontera a Europa: una visión desde la cooperación transfronteriza", in FERIA J. M., GARCÍA A. and OJEDA F. (Edș)

Territorios, Sociedades y Políticas, pp. 495-510. AGE, Sevilla.

TRILLO-SANTAMARÍA J. M. (2010) La région transfrontalière: des idées de Rougemont aux processus actuels d'institutionnalisation, Revue Mosella 23(1/4), 241-

Deleted: “ Deleted: 264.

VELDE M. van der and HOUTUM H. van (2003)_Communicating Borders, Journal of Borderland Studies 18(1), 1-11. 


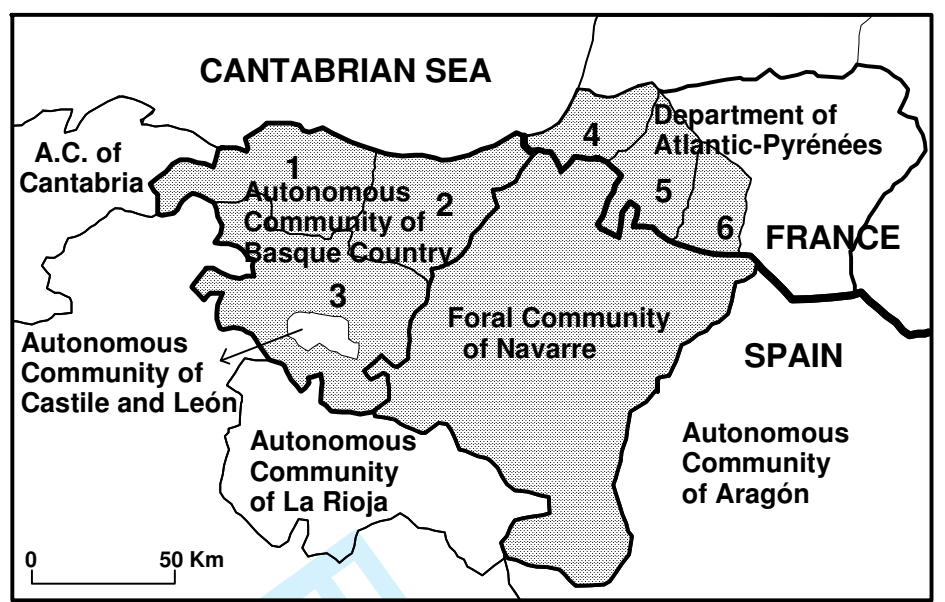

Spanish Basque

administrative provinces

("Territorios Históricos"):

1. Vizcaya

2. Guipúzcoa

3. Álava

French Basque historic provinces:

4. Labourd

5. Lower Navarre

6. Soule

Fig. 1. Territorial components of Euskal Herria, according to Basque nationalism imagination 


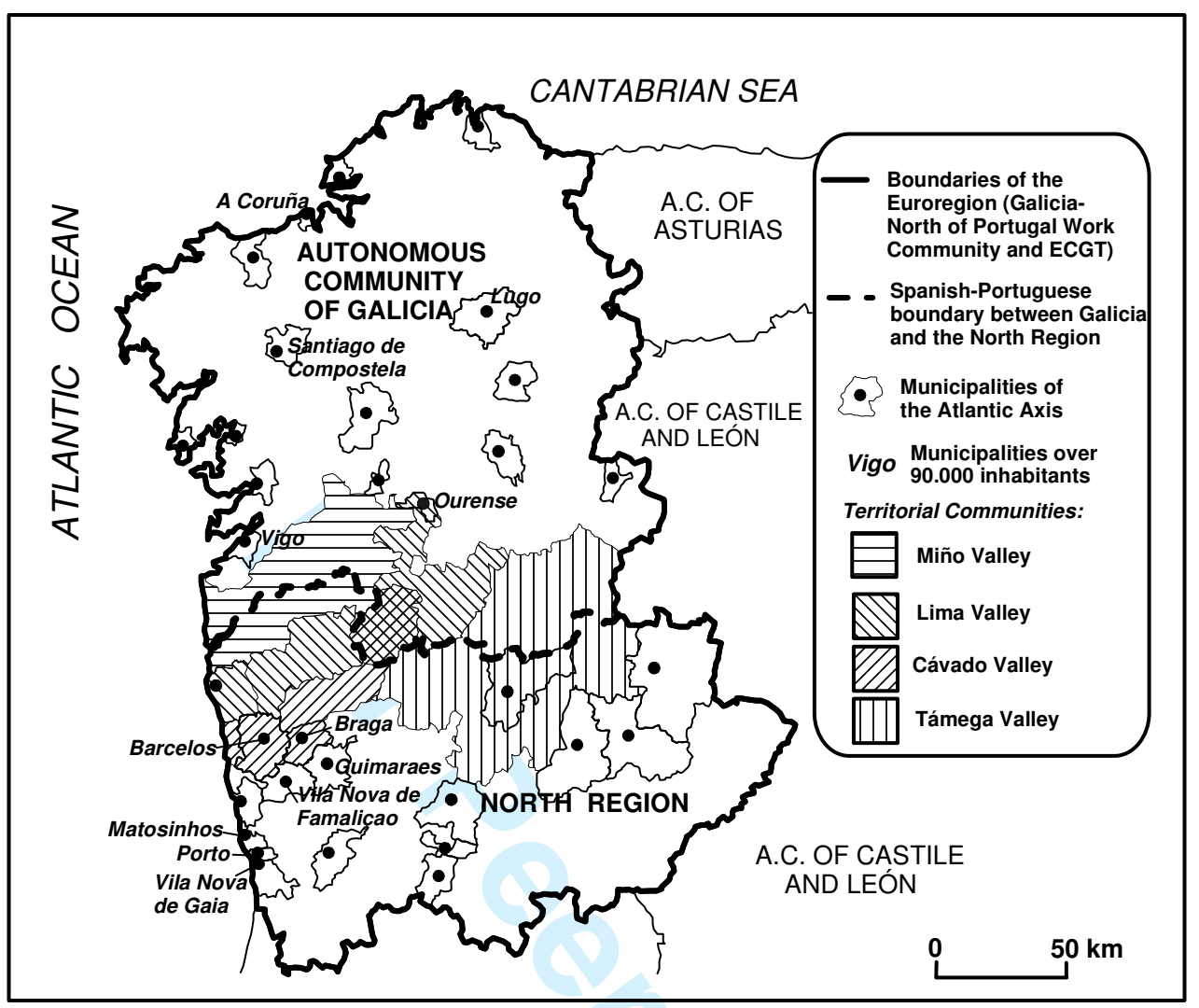

Fig. 2. Cross-border cooperation spatial structures in the Galicia-North of Portugal Euroregion 